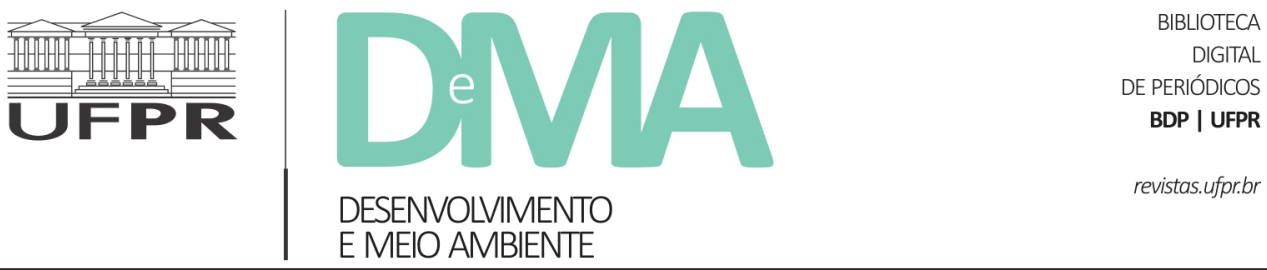

\title{
Dimensão ambiental na agenda política da CEPAL: equação ainda pendente
}

\section{Environmental dimension in the political agenda of the ECLAC: still pending equation}

\author{
Flora Moritz da SILVA ${ }^{*}$, Gilberto SALES ${ }^{2}$, Silvio Antônio Ferraz CÁRIO ${ }^{1}$, Hans Michael Van BELLEN ${ }^{1}$ \\ ${ }^{1}$ Universidade Federal de Santa Catarina (UFSC), Florianópolis, SC, Brasil. \\ ${ }^{2}$ Instituto Chico Mendes de Conservação da Biodiversidade (ICMBio), Itajaí, SC, Brasil. \\ *E-mail de contato: floramds@gmail.com
}

Artigo recebido em 7 de novembro de 2020, versão final aceita em 18 de abril de 2021, publicado em 10 de novembro de 2021.

\begin{abstract}
RESUMO: A Comissão Econômica para a América Latina e o Caribe (CEPAL) é uma referência na configuração de modelos de desenvolvimento na região, desde sua criação, em meados do século XX. Neste ensaio, o objetivo é analisar a forma de incorporar a preocupação com o meio ambiente nas dimensões do desenvolvimento, pregada pela CEPAL, de 2000 a 2020, expressas nos seus principais documentos. Nesse propósito enfatiza-se em que momentos, em que medida e de que forma a dimensão ambiental, com o sentido de preocupação estratégica com relação à natureza, aparece no contexto das preocupações e modelos de desenvolvimento da CEPAL. A pesquisa, caracterizada como qualitativa, descritiva explicativa e com abordagem histórica, foi realizada a partir de análise bibliográfica e documental, com foco em documentos estratégicos produzidos pela CEPAL. Os documentos analisados resultaram dos encontros bienais, nos quais os 44 Estados membros, representantes do sistema da ONU e de organizações não governamentais se reúnem para examinar as atividades realizadas e elencar as prioridades futuras, definindo as estratégias desenvolvimentistas. O resultado da análise evidenciou que as dimensões econômica e social têm sido as principais preocupações da organização, definidas como estratégicas para o crescimento, impulsionado pela industrialização, desenvolvimento tecnológico e pela promoção da igualdade. A dimensão ambiental tomou corpo na agenda cepalina nos anos 2000, sendo pontuada nos documentos estratégicos, porém não com a mesma importância que as áreas econômica e social, constituindo, portanto, uma equação ainda pendente. A atenção com o meio ambiente aparece de maneira subsidiária e espasmódica, pautada por movimentos internacionais; e tardia, como algo almejado e nunca objetivado, a ponto de gerar metas ou indicadores que estimulem a incorporação da dimensão ambiental, como elemento essencial e prioritário para o desenvolvimento de países da região.
\end{abstract}

Palavras-chave: desenvolvimento; meio ambiente; sustentabilidade; CEPAL. 
ABSTRACT: The Economic Commission for Latin America and the Caribbean (ECLAC) has been a reference in shaping development models in the region since its creation in the mid-20th century. The purpose of this essay is to analyze how the theme of the environment appears in development models preached from 2000 to 2020 by ECLAC, expressed in its main documents. In this regard, it is important to emphasize when, to what extent and in what way the environmental dimension, with a sense of strategic concern for nature, appears in the context of ECLAC's concerns and development models. This research is characterized as descriptive, explanatory and with a historical approach, based on bibliographic and documentary analysis, focusing on strategic documents produced by ECLAC. The analyzed documents resulted from the biennial meetings, in which the 44 member states, representatives of the UN system and non-governmental organizations come together to examine the activities carried out and to list future priorities, defining developmental strategies. The result of the analysis showed that the economic and social dimensions have been the main concerns of the organization, defined as strategic for growth, driven by industrialization, technological development and the promotion of equality. The environmental dimension took shape in the ECLAC agenda in the 2000s, being punctuated in the strategic documents, but not with the same importance as the economic and social areas, constituting, therefore, an equation still pending. Attention to the environment appears in a subsidiary and spasmodic manner, guided by international movements; and belatedly, as something desired and never objectified, to the point of generating goals or indicators that encourage the incorporation of the environmental dimension, as an essential and priority element for the development of countries in the region.

Keywords: development; environment; sustainability; ECLAC.

\section{Introdução}

Desde meados do século XX, a evolução do pensamento e da prática em torno das estratégias de desenvolvimento na América Latina tem como uma das principais referências estudos da Comissão Econômica para a América Latina e o Caribe (CEPAL), órgão vinculado à Organização das Nações Unidas (ONU). A criação desse órgão no imediato pós $2^{\mathrm{a}}$ Guerra Mundial ocorreu ancorada na geocultura do desenvolvimento capitalista, com intuito de produzir conhecimentos que dessem suporte para aplicação de políticas públicas a governos da região. Desde seu início, a instituição contou com equipe técnica de elevada capacidade intelectual, formada por representantes procedentes de diferentes países membros, os quais, ao longo do tempo, foram incorporando preocupações, prioridades e dimensões econômicas, políticas e sociais, alinhadas aos ideários de desenvolvimento.
No decorrer do tempo, várias teses desenvolvimentistas marcaram o percurso da CEPAL, podendo se citar posicionamentos, como: em defesa da industrialização como caminho para superação do atraso, conforme caminho trilhado pelos países centrais; eleição do Estado como ator representativo no exercício das funções de planejador, interventor e produtor com propósito de acelerar as condições de desenvolvimento; a favor do desenvolvimento do progresso técnico, considerado vital para reduzir a heterogeneidade produtiva e superar a dependência tecnológica externa; e defesa da transformação com equidade social, igualdade de oportunidades e inclusão social.

$\mathrm{O}$ tema do meio ambiente, no curso de pouco mais de sete décadas de existência institucional, não tomou, efetivamente, corpo na agenda cepalina até o ano 2000. Ao longo de várias décadas foi pouco pontuado nos documentos, ainda que tenha sido realçado em alguns momentos, sob a influência de 
conferências e convenções internacionais, tendo a ONU, como um dos organizadores. Nesse item, destaque deve ser dado para dois documentos: o primeiro, coordenado por Sunkel \& Glico (1981), questionando o estilo de desenvolvimento e as consequências ao meio ambiente; e o segundo, coordenado por Fernando Fajnzylber, CEPAL (1996), sinalizando que a transformação produtiva com equidade deveria levar em pauta o respeito ao meio ambiente. Nesse período, as preocupações maiores na região ficaram por conta de questões econômicas (estabilidade macroeconômica e reestruturação produtiva) e sociais (redução da pobreza e melhoria educacional).

A partir dos anos 2000, no entanto, a questão ambiental passou a ser colocada com maior ênfase no conjunto de preocupações e orientações desenvolvimentistas da CEPAL. A temática propagou-se nos documentos correntes, sobretudo naqueles derivados dos encontros bienais nos quais os 44 Estados membros, representantes do sistema da ONU e de organizações não governamentais se reúnem, para examinar as atividades realizadas e elencar as prioridades futuras (ONU, 2014), definindo estratégias desenvolvimentistas nos campos econômico, social, político, ambiental etc. Dentre as novas orientações, citam-se: trabalhar pela transformação da base produtiva, fundada no conhecimento e de menor impacto ambiental; defender a utilização de matriz energética renovável no curso da transformação produtiva; reivindicar a participação do Estado, para que contribua financiando, subsidiando e incentivando atividades produtivas limpas; e estimular a criação de governança ambiental a partir de pactos sociais.

Considerando esses aspectos, o objetivo deste artigo é analisar como vem sendo incorporada a preocupação com o meio ambiente nas dimensões do desenvolvimento, pregadas pela CEPAL nas duas últimas décadas, 2000-2020, expressas nos principais documentos dessa organização. Enfatizar em que momentos, em que medida e de que forma a dimensão ambiental, com o sentido de preocupação estratégica em relação à natureza, aparece no contexto das preocupações e nos modelos de desenvolvimento dessa instituição.

Para tanto, estruturou-se o artigo em cinco seções. Na primeira seção, expõe-se o objetivo principal; na segunda, aponta-se o procedimento metodológico; na terceira, descrevem-se, de forma sintética, a criação da CEPAL no bojo do debate sobre desenvolvimento, e o curso de suas principais preocupações ao longo do tempo; na quarta seção, apresenta-se a dimensão ambiental na matriz dos estudos da CEPAL; e, por fim na quinta, em conclusão, faz-se uma avaliação geral dos fatos, fatores e contextos revelados.

\section{Procedimentos metodológicos}

O estudo foi realizado sob investigação de natureza qualitativa, do tipo descritiva e explicativa, e segundo abordagem histórica. Através da pesquisa qualitativa, foi possível explorar, entender e analisar os significados do objeto da pesquisa, a partir da coleta de informações (Marconi \& Lakattos, 2003). Além disso, possibilitou investigar documentos, traços de experiências e interações existentes (Gibbs, 2009). Quanto ao tipo de pesquisa, optou-se pelo caráter descritivo e explicativo, uma vez que se buscava descrever os fatos e fenômenos de determinada realidade, de forma a obter informações a respeito daquilo que já se definiu como proble- 
ma a ser investigado, possibilitando, assim, uma explicação para o fenômeno (Triviños, 2007; Gil, 2008). Para o desenvolvimento do tema, adotou-se a abordagem histórica, de recorte longitudinal, cuja construção do objeto de estudo percorreu a trajetória do passado ao presente momento.

A fonte de informação que deu base à pesquisa foram os documentos elaborados pela CEPAL. Na perspectiva documental, foram consultadas as publicações gerais, governamentais e institucionais da CEPAL, seus documentos estratégicos, que trazem a visão dos movimentos estruturantes e das ideologias e abordagens teóricas mais fortes, na delimitação das correntes debatidas e difundidas por esse organismo.

Nessa linha, foram considerados documentos estratégicos: a) o livro Cinquenta anos de pensamento na CEPAL, organizado por Bielschowsky (2000); b) o livro: Sesenta años de la CEPAL: textos seleccionados del decênio 1998-2008, compilado por Ricardo Bielschowsky (2010); c) os artigos que tratam da evolução das ideias da CEPAL, como o número extraordinário de texto da CEPAL (2013) denominado "Informação histórica: evolução das ideias da Cepal"; e d) a página eletrônica da CEPAL, principalmente os documentos oficiais dos Períodos de Sessões CEPAL, de 2000 a 2020, dos quais foram destacadas as ideias e conceitos relevantes para o enfoque aplicado neste trabalho.

\section{Evolução das principais ideias e dimensões do desenvolvimento na CEPAL}

\author{
3.1. Criação da CEPAL no bojo do debate \\ sobre o desenvolvimento econômico
}

Considera-se desenvolvimento um processo de transformação econômica, política e social. Trata-se, assim, de uma ordem transformadora, de mudança, de alteração, enfim de modificação da estrutura da sociedade. Nessa linha, para Bresser Pereira (2006), o aspecto econômico é preponderante, pois, a partir dele, é possível propor o crescimento do padrão de vida da população, de forma automática e autônoma. E, Bielschowsky (2007) defende que o projeto de mudança passa pela natureza econômica, como primeira instância, sendo a indústria a via para superação da pobreza e do subdesenvolvimento.

No entendimento de Bresser Pereira (2012a; 2012b), desenvolvimento não é uma palavra de ordem a mais no vocabulário, mas sim uma palavra que unifica ações, sobretudo do Estado como instrumento de construção de condições para levar a sociedade para um estágio superior. Essa manifestação é formada por ações, determinação, vontade e planejamento. Para tanto, o Estado tem papel central na execução dessa tarefa. Tal proposição encontra sustentação, visto que o desenvolvimento ocorre por meio de ação estatal praticada no exercício de política econômica pelos governos, visando transformar a sociedade na direção de alcançar fins desejáveis (Fonseca, 2000; 2014).

No âmbito do significado e da promoção do desenvolvimento foi criada a CEPAL, como órgão da Organização das Nações Unidas (ONU) para o desenvolvimento da região da América Latina e Caribe. A CEPAL é fruto de debates sobre os caminhos do desenvolvimento, que vinham ocorrendo em anos anteriores a sua criação. Como observa Fiori (1999, apud Prado, 2015), com o final da $2^{\mathrm{a}}$ Grande Guerra Mundial, ocorreu uma geocultura do desenvolvimento, estabelecendo ampla produção 
de conhecimento e aplicação de políticas públicas, como um objetivo a ser alcançado por diversos países. Na área capitalista, os EUA capitanearam projetos de desenvolvimento, criando novos mercados, integrando sistemas de produção, financiando reconstruções e investimentos, em países afetados pela guerra e em áreas de países subdesenvolvidos. Foram criados o Banco Internacional de Reconstrução e Desenvolvimento (BIRD), o Acordo Geral de Comércio e Tarifa (GATT) e o Fundo Monetário Internacional (FMI) (Teixeira, 1983).

Nesse rastro de criação de um quadro de apoio institucional ao desenvolvimento do pós $2^{\mathrm{a}}$ Guerra, a ONU delegou ao Conselho Econômico e Social (ECOSOC), a função de criar Comissões Econômicas Regionais com finalidade de promover a cooperação para o desenvolvimento. Segundo Prado (2015), a partir de 1947, foram criadas comissões, primeiro para a Europa, Ásia e Extremo Oriente; depois, em 1948 para a América Latina, a qual, a partir de 1984, passou a ser denominada Comissão Econômica para a América Latina (CEPAL). A CEPAL foi vista como a "mais original e ativa entre as várias organizações regionais estabelecidas pelas Nações Unidas no período do pós-guerra" (Kay 1989, p. 60, apud Prado, 2015, p. 231).

Com a criação da CEPAL, amplo espaço de reflexão sobre economia do desenvolvimento foi estabelecido, colocando em pauta a busca de respostas para as perguntas: Como superar os obstáculos do subdesenvolvimento? Como desenvolver países com realidades distintas? Em resposta, intelectuais latino-americanos, como Raul Prebisch, Anibal Pinto e Celso Furtado, e europeus, como Gino Germani e José Medina Echavarria entre outros, realizaram revoluções teórica e analítica pautadas sob a ideo- logia do desenvolvimento para países periféricos. Nesse sentido, a comissão sempre contou com intelectuais, que contribuíram para o surgimento de um pensamento que buscava, através de análise histórica-estrutural, realizar diagnósticos e sugerir políticas e instrumentos voltados à promoção do desenvolvimento (Prado, 2015).

As realidades econômica e política existentes nos países da região auxiliaram, fortemente, na condução das análises realizadas. Em muitos países, como Argentina, Chile, México, Uruguai e Brasil, ascendeu ao poder uma burguesia industrial, em compromisso com a oligarquia primário-exportadora, desenvolvedora de uma ideologia voltada à industrialização, como meio para alcançar o desenvolvimento (Prado, 2015). No Brasil, imperava o desenvolvimento segundo um padrão de intervenção pautado pela autonomia relativa do Estado, em que as forças políticas e econômicas não eram suficientemente fortes para impor um projeto, permitindo ao Estado atuar como condutor ativo do desenvolvimento em compromisso com essas forças existentes (Draibe, 1985).

As características estruturais que marcaram, à época, a economia periférica regional foram expostas por Bielschowsky (2001) e Colistete (2001), indicadas como: baixa diversidade produtiva; reduzida integração vertical e horizontal; insuficiente infraestrutura; especialização em bens primários; heterogeneidade tecnológica; oferta ilimitada da mão de obra; e renda ao nível de subsistência. Sob este quadro, a CEPAL desenhou a proposta de industrialização com base na intervenção do Estado, através da qual poderia substituir importações; criar estrutura produtiva integrada - produção de insumos e bens de capital para a produção de bens finais; centralizar recursos internos para financiamentos de 
longo prazo; desenvolver sistema de planejamento público, etc.

Como observa Bielschowsky (2010), a CEPAL foi criada com objetivo de analisar as especificidades do desenvolvimento dos países latino-americanos e caribenhos nos campos econômico, social, institucional e internacional. Nessa perspectiva, o método de análise de seus trabalhos percorre aspectos teóricos e analíticos histórico-estrutural, que se transforma em linha com a organização e dinâmica econômica capitalista. Assim, sem deixar de manter as especificidades estruturais dos países dessa região, ela vai adequando, ajustando e respondendo suas análises às mudanças que ocorrem no passar do tempo.

\subsection{O curso das principais preocupações $d a$ CEPAL ao longo do tempo}

O marco original do estruturalismo cepalino, que influenciou os estudos dos anos 1950, pautou-se pelo trabalho clássico de Prebisch (1973), em que se contrapõem as características das economias periféricas - primárias exportadoras - frente às economias centrais - industrializadas - nas relações econômicas. Em seu teor, a manter o quadro existente, significava reforçar a assimetria entre o dinamismo da economia mundial demandadora de produtos primários, diante de uma periferia pautada pela procura por produtos industrializados originados do centro, sempre trocados em condições desfavoráveis. Diante disso, os problemas estruturais se reproduziram, provocando desequilíbrio na balança de pagamentos, insuficiência de divisas externas, efeitos negativos no processo inflacionário, limitada geração de emprego e renda interna etc. A industrialização, a exemplo da realizada pelos países centrais, constituía o caminho a ser perseguido. Nesses termos, cabia ao Estado conduzir, de forma deliberada, esse processo de industrialização latino-americano, realizado através do mecanismo de processo de substituição de importações (Draibe, 1985; Cardoso de Mello, 1998).

Nos anos 1960, a CEPAL manteve a defesa da industrialização. Vivia-se um período de ingresso acelerado de empresas multinacionais nas economias latino-americanas e caribenhas, que viam a possibilidade de desenvolvimento, em momento de plena luta por ocupação de espaços das empresas multinacionais norte-americanas, europeias e asiáticas pós 2a . Guerra Mundial (Teixeira, 1983). Contudo, os estudos cepalinos foram mostrando que, ao lado do processo de modernização via industrialização, perfilavam problemas postos pela nova modalidade de pobreza, pelo desequilíbrio social e pelo crescimento urbano desordenado ao lado dos já existentes desequilíbrios estruturais do balanço de pagamentos e da inflação.

Estudos da CEPAL e do entorno dessa instituição apontavam o caráter dependente do processo de modernização em curso. No âmbito da CEPAL, destaque deve ser dado para as formas de dependência de capitais, apontadas por Sunkel (1967), e a política, pelos escritos de Cardoso \& Faletto (1970); enquanto, no âmbito externo, vigorava o tratamento da dependência através da exploração da força de trabalho pelo capital internacional, de autoria de Marini (1990; 2011). Somavam-se, ainda, as visões críticas de Furtado (1992) e Tavares \& Serra (2000) de que os países, em particular o Brasil, se industrializaram sem resolver os problemas de geração de emprego e renda. A CEPAL, a partir da realidade posta, suscitava que os países fizessem 
reformas - agrária, educacional, financeira, fiscal e política - para dar continuidade ao processo de industrialização, dado que somente a orientação à industrialização não viabilizava o desenvolvimento.

A década de 70 marca a orientação cepalina continuada em favor da industrialização, porém acompanhada de crítica pelo excesso de protecionismo em que estava se configurando. $\mathrm{O}$ marco regulatório de apoio à industrialização limitava a concorrência posta por barreiras tarifárias e não tarifárias, privilegiando empresas no mercado doméstico em relação à concorrência externa. Esse processo contribuía para a lentidão de investimentos em favor do progresso tecnológico, bem como para a elaboração de estratégias de crescimento ativas e menos dependentes. Nessa década, o momento vivido pela economia mundial era de excesso de liquidez, que, em face do padrão de financiamento insuficiente, fizeram as economias adentrarem o caminho do endividamento (Batista, 1983; Cruz, 1984). O objetivo de crescer com endividamento externo tornou-se o rito dos países, a despeito da orientação cepalina ser de cuidado, dado que poderia constituir caminho perigoso, se praticado em excesso.

Nessa trajetória, a CEPAL pregou que a industrialização fosse orientada no sentido de atender tanto o mercado interno quanto o externo. No tocante ao mercado interno, o propósito era gerar efeitos dinâmicos de crescimento do produto, da renda e do emprego; e, em relação ao mercado externo, este deveria ter amplitude regional e mundial, visando fortalecer relações entre países da região, ter inserção ativa no mercado externo e gerar divisas para enfrentamento propositivo das contas do balanço de pagamento. Alguns países se valeram dessa orientação para impulsionar exportações industriais com incentivos fiscais e financeiros, e, assim, poder melhor enfrentar os problemas de insuficiência exportadora reinante (Bielschowsky, 2010).

Um ponto importante a ser destacado nas orientações cepalinas, nos anos 1970, refere-se à preocupação com a distribuição de renda. Várias economias da região apresentaram crescimento significativo do produto interno bruto (PIB), porém os frutos desse crescimento não foram distribuídos para a maioria dos participantes. Para a CEPAL, o processo de desenvolvimento criava, do lado da oferta, empresas detentoras do capital e de progresso técnico; e, do lado da demanda, estrutura de consumo marcada pela concentração de renda garantidora de acesso aos produtos de maior valor agregado. A estrutura de oferta reproduzia a modalidade tecnológica dos países centrais, de uso intenso de capitais e pouco absorvedora de mão de obra, como salientava Celso Furtado em sua vasta obra (Almeida, 2009). Nessa linha, os países latino-americanos apresentavam elevada oferta de mão de obra e de reduzida qualificação, resultando em acesso ao trabalho e ganhos salariais distintos (Bielschowsky, 2010).

Nos anos 80, a CEPAL pautou-se pelo tratamento da trilogia dívida - inflação - ajuste, assim denominada por Bielschowsky (2010), e construída no curso de décadas anteriores, quando os governos aproveitaram o fluxo de capitais financeiros disponíveis e taxas de juros baixas para promoverem o crescimento econômico. Envolvidos em projetos de investimentos, os setores público e privado assumiram compromissos com o sistema financeiro internacional. Esse cenário alterou-se em fins dos anos 70 . Com a política de retomada da hegemonia norte-americana, pautada pela elevação da taxa de 
juros e dólar forte, muitos países se depararam com desequilíbrios no balanço de pagamento, perda de dinamismo econômico, fragilidade financeira do Estado, inflação acentuada, entre outros problemas (Tavares, 1985). Diante da preocupação com a asfixia financeira dos países membros, perdeu importância, na CEPAL, a agenda atribuída ao desenvolvimento produtivo e distributivo.

A CEPAL aconselhava os países a renegociarem a dívida externa sem desconsiderar a necessidade de promover o crescimento econômico, promover investimento e controlar o índice inflacionário. Contudo, o sistema financeiro internacional, fortemente atemorizado pelo número de países devedores que pediram moratória no início da década, manteve-se inflexível às renegociações. $\mathrm{O}$ tratamento individualizado pelo sistema financeiro internacional, sob coordenação do FMI, em cada renegociação, enfraquecia o poder de negociação do país devedor (Portela Filho, 1987). Por consequência, os países foram obrigados a fazer ajustes internos severos para cumprir seus compromissos externos. A política macroeconômica praticada reduziu fortemente o crescimento, levando essa década a ser considerada como "década perdida" (Carneiro, 2002).

Por sua vez, ainda que perdendo luz na agenda cepalina, diante da asfixia financeira com a qual se deparavam os países, a instituição não deixou de produzir documentos que analisavam a estrutura produtiva e distributiva. Nesse sentido, marcaram, de forma enfática, as contribuições de Fajnzylber (1983; 1990), que sinalizavam a renovação das ideias estruturalistas nos anos 1990. As duas obras referenciadas, respectivamente, "La industrialización trunca de América Latina" e "Industrialización em América Latina: de la 'caja negra' al casillero vacio", reportaram caminhos cruciais na orientação analítica dos trabalhos da CEPAL, que se seguiu posteriormente (Bielschowsky, 2010).

No primeiro trabalho, "La industrialización trunca de América Latina", Fajnzylber reforça a tese cepalina da existência de problemas estruturais na América Latina que impedem o desenvolvimento da região, dentre os quais citam-se: mercado interno concentrado para consumo de alta renda; reduzida integração da indústria com a agricultura; baixa produtividade; e problemas de balanço de pagamentos, que limitavam o crescimento econômico. A superação desses entraves deveria vir a partir da participação ativa e qualificada do Estado (Fajnzylber, 1983; Bielschowsky, 2010). Para sustentar sua defesa, recorre às experiências vivenciadas pelos países asiáticos (Coreia do Sul e Taiwan, por ex.), onde a atuação do Estado foi pautada pelo protecionismo, com intuito de desenvolver aprendizagem tecnológica e não por um protecionismo frívolo, que contribuísse para manter uma industrialização trunca, incompleta e inacabada. Nessa linha, sinaliza a importância de criar condições para o desenvolvimento endógeno em favor do progresso técnico (Fajnzylber, 1983; Olivos, 2006).

Nesse curso, a nova industrialização proposta deveria se pautar pelo binômio crescimento e criatividade, cuja pauta industrializante deveria ser da construção de um núcleo endógeno do progresso técnico, que possibilitaria reduzir a dependência de bens de capital estrangeiro, irradiar efeitos internos para frente e para trás nas cadeias produtivas e ter inserção externa dinâmica, baseada em tecnologia e não fundada em incentivos fiscais, baixos salários e desvalorização cambial (Bielschowsky, 2010). Na nova orientação do modelo de desenvolvimento encontrava-se o rompimento com a estrutura de 
produção direcionada para o consumo para uma minoria. E, posicionava-se em favor de estrutura produtiva voltada em atender o consumo da maioria da população, corroborado por mecanismos de melhor distribuição de renda (Olivos, 2006).

Por sua vez, no segundo trabalho, "Industrialización em América Latina: de la caja negra al casillero vacio", Fajnzylber (1990), novamente, em estudo comparativo de países, mostra que, entre os países de abrangência de estudo e de proposição de políticas de desenvolvimento da CEPAL, nenhum integrou grupo ideal em que estavam presentes crescimento com distribuição de renda. Por outro lado, alguns tiveram melhoria na distribuição de renda, porém sem verificação de crescimento. E, outros, ainda, em pior situação, registraram crescimento econômico, contudo, com inexistente distribuição de renda. Tal quadro diferenciava-se de outros países (Coreia do Sul, Espanha e Hungria, como ex.), que promoveram o crescimento com distribuição de renda. Nesse curso, a orientação cepalina deveria se pautar por ações voltadas para o crescimento com equidade social (Fajnzylber, 1990; Paiva, 2006; Bielschowsky, 2010).

Os anos 1990 foram marcados por forte recomendação do Consenso de Washington, que pregava a abertura de mercado, a desregulamentação econômica, a privatização de empresas e a redução da intervenção estatal (Batista, 1994). A CEPAL procurou adequar-se às medidas institucionais do novo padrão de diretrizes da economia mundial, resistindo, contudo, através de seus documentos, à intensidade de adoção das medidas em face das características estruturais dos países. Reconhecia, assim, a necessidade de reposicionar a atuação do Estado frente a esse novo quadro, porém ressaltava sua importância na agenda de desenvolvimento.
Documentos reforçaram a defesa do crescimento econômico com justiça social, em particular o "Transformación productiva com equidade", elaborado no ano de 1990. A abertura econômica, por exemplo, um dos pilares do Consenso de Washington, deveria ser lenta, gradual, seletiva e protegida. Deveria ser amparada por condições que gerassem competitividade, baseada nas capacidades produtivas e inovativas, sistêmica e com interconexão de várias políticas: infraestrutural, macroeconômica, educacional, industrial e tecnológica.

Segundo Torres (2006), o documento base das ações da CEPAL, transformação com equidade de 1990, reforçou a orientação em favor da redução do hiato de equidade, dada a desigualdade social existente na região. Para alcançar tal intento, requeriam-se melhorias nas condições produtivas, tecnológicas e institucionais. Logo, a defesa da instituição pela construção de um sistema industrial que incorporasse o progresso técnico, para aumentar a produtividade e a competitividade. Para que tal construção ocorresse, deveriam ocorrer encadeamentos para frente e para trás entre os elos produtivos. O documento recomendava a necessidade de ação institucional organizada, de vários atores - empresas, governos, universidades, associações etc. - em prol da inovação e do progresso técnico. O caminho trilhado pautava-se pela transformação da base produtiva e pela redução do distanciamento social existente (CEPAL, 1996).

No final da década, passados vários anos de abertura econômica, desregulamentação e privatização de empresas estatais, os documentos cepalinos apontaram que, para superar o atraso econômico regional, somente políticas de cunho neoliberal não bastavam; havia necessidade de promover transformações estruturais. Proposições de revisão 
da abertura financeira e em favor do fortalecimento e renovação da política industrial e tecnológica e de comércio exterior, de reformas sociais abrangentes e da defesa da sustentabilidade ambiental passaram a se fazer presentes nos documentos. Do mesmo modo encontrava-se presente a defesa de gestão de política macroeconômica, equilibrada em relação às contas do balanço de pagamento, finanças públicas e ao sistema monetário (Bielschowsky, 2010).

Nos anos 2000, com destaque para a primeira década, as orientações da CEPAL primaram por temas em torno da atualização dos fundamentos estruturalistas ao lado do enfrentamento das condições impostas pela globalização. Os documentos reforçavam as bases neoestruturalistas de que as transformações produtivas devem ser fundadas no progresso técnico, dentre outros propósitos, permitir inserção ativa no comércio internacional. Além disso, davam ênfase aos temas sociais, estendendo-se não só à equidade social, mas aos direitos, à cidadania e à coesão social (CEPAL, 2007a; 2007b). Os documentos reforçaram, ainda, a visão crítica às diretrizes de reformas postas pela globalização, que procuravam impor regras econômicas, sem atentar para as especificidades regionais. Um dos principais documentos fez defesa da política nacional, estimulando a implementação de políticas anticíclicas para enfrentamento da crise e das condições impostas pelo sistema financeiro internacional (CEPAL, 2002b).

No tocante à preocupação em transformar a base produtiva, a CEPAL elegeu a inovação como determinante para o desenvolvimento. Não que a inovação, na sua expressão de progresso técnico, deixasse de estar presente ao longo das orientações estruturalistas, mas reforçava-se a dimensão sistêmica para seu desenvolvimento. A comissão destacou a importância das instituições de apoio - universidade, governo, bancos, associações etc. e indicou que o desenvolvimento inovativo deve levar em consideração as cadeias produtivas, por fortalecer e envolver vários segmentos produtivos. Apoiou o desenvolvimento de aglomerações produtivas localizadas, pautadas pela cooperação e integração de seus atores. Nisso, a CEPAL buscava criar condições para reduzir a heterogeneidade estrutural - hiato entre setores modernos e atrasados -, fonte geradora de baixa produtividade, diminuta competitividade, promotora de diferenciação salarial e, por extensão, do aumento da disparidade social.

A CEPAL, em seus documentos, postou-se de forma enfática, defendendo que a transformação produtiva, fundada na inovação, permite a ocorrência, ao mesmo tempo, da diversificação e especialização produtiva, fortalecendo, no conjunto, a estrutura produtiva. A estrutura produtiva com essas qualidades cria condições para as exportações, fazendo do comércio exterior um determinante para o crescimento econômico. Nesse entendimento, os efeitos puxados pela participação ativa no comércio exterior podem gerar efeitos multiplicadores do crescimento interno - produto, renda e emprego -, bem como reduzir a vulnerabilidade do balanço de pagamentos (CEPAL 2007c).

Nos anos 2000, reacendeu-se a preocupação da CEPAL com o desenvolvimento social. Esse tema inseriu como marco da instituição: sempre vincular a estrutura econômica e a estrutura social. Os documentos apontaram que a pobreza e a concentração de renda existentes na região latino-americana decorrem da estrutura econômica, marcada por forte heterogeneidade. Nesse quadro, a má distribuição dos ativos produtivos (altamente concentrados) e dos ativos sociais (distinto acesso ao crédito, à informação, à tecnologia, à educação e à saúde) 
impede o desenvolvimento social (Bielschowsky, 2010); e destaca a fragilidade dos mecanismos de acesso às oportunidades de fontes de geração de riqueza, como a educação, a tecnologia e o crédito (Bárcena, 2014). A comissão postou-se em defesa do tema igualdade de oportunidade das pessoas à educação, saúde, habitação, saneamento básico etc., como pilares para a mudança social (CEPAL 2007a). A Tabela 1 sintetiza os elementos analíticos do pensamento cepalino.

Ainda nesses anos 2000, foi retomado um dos temas relevantes levado a cabo pela CEPAL, isto é: a gestão macroeconômica. Na área fiscal, a comissão orientou os países para o ajuste fiscal, o aumento da produtividade da gestão pública e a transparência das informações. Na área cambial, enfatizou a responsabilidade dos governos nas prá-

TABELA 1 - Síntese dos elementos analíticos que compõem o pensamento cepalino.

\begin{tabular}{llcl}
\hline \multirow{2}{*}{ Períodos e Temas } & \multicolumn{2}{c}{ Análise histórico-estruturalista } \\
\cline { 2 - 3 } & Inserção Internacional & Condições Estruturais Internas & Ação Estatal
\end{tabular}
1948-1960 (Industriali-
zação)
Deterioração dos termos de intercâmbio; desequilíbrio estrutural na balança de pagamentos; e integração regional.
Processo de industrialização substitutiva; tendências perversas causadas por especiali- Conduzir deliberadamenzação e heterogeneidade estrutural; e inflação te a industrialização. estrutural e desemprego.

\begin{tabular}{ll}
\hline $\mathbf{1 9 6 0}$ & $\begin{array}{l}\text { Dependência, integração regio- } \\
\text { nal; política internacional de } \\
\text { redução da vulnerabilidade na } \\
\text { periferia; viés antiexportação } \\
\text { industrial. }\end{array}$ \\
$\begin{array}{l}\text { Reformas para desobs- } \\
\text { truir a industrialização) }\end{array}$ & $\begin{array}{l}\text { Dependência; endividamento } \\
\text { perigoso; e insuficiência expor- } \\
\text { tadora. }\end{array}$ \\
\hline $\mathbf{1 9 7 0}$ &
\end{tabular}

\section{0}

(Dívida)
Asfixia financeira.

\section{0-98 (Transformação} produtiva com equidade)
Especialização exportadora ineficaz; e vulnerabilidade aos movimentos de capitais.
Reforma agrária e distribuição da renda como requisito para a redinamização da economia; heterogeneidade estrutural; e dependência.
Reformar para viabilizar o desenvolvimento.
Estilos de crescimento, estrutura produtiva e distributiva e estruturas de poder; e industrialização combinando mercado interno e esforço exportador.

Ajuste com crescimento; oposição aos choques do ajuste; necessidade de políticas de renda e conveniência de choques de estabilização; e custo social do ajuste.

Dificuldades para uma transformação produtiva eficaz; e para reduzir o hiato da equidade.
Viabilizar estilo que leve à homogeneidade social; e fortalecer exportações industriais.

Renegociar a dívida para ajustar com crescimento.

Implementar políticas de fortalecimento da transformação produtiva com equidade.

\begin{tabular}{ll}
\hline Anos 2000 & Gestão macroeconômica; \\
$\begin{array}{ll}\text { (Macroeconomia e hete- } \\
\text { rogeneidade social) }\end{array}$ & $\begin{array}{l}\text { Responsabilidade cambial e } \\
\text { fiscal. }\end{array}$
\end{tabular}

Heterogeneidade social persistente e dificuldades estruturais para mobilidade social.
Redistribuição de ativos produtivos e fontes de geração de riquezas.

FONTE: Bielschowsky $(2000 ; 2010)$ e complementado pelos autores. 
ticas de valorização e de desvalorização cambial, que, dependendo da orientação, podem provocar desequilíbrio no balanço de pagamentos, impactar os preços domésticos, elevar o endividamento externo, estimular a desindustrialização, entre outros. $\mathrm{Na}$ área das finanças, chamou a atenção para a volatilidade de capital que estão sujeitas às economias, podendo levar à fuga de capitais comprometedora da estabilidade macroeconômica (Bielschowsky, 2010).

\section{Dimensão ambiental na matriz do pensamento da CEPAL}

\subsection{Desenvolvimento e meio ambiente: das preocupações iniciais dos anos 1970 à presença maior do tema na agenda desenvolvimentista nos anos 1990}

As primeiras incursões da CEPAL sobre o tema desenvolvimento e meio ambiente ocorreu na década de 1970, notadamente no primeiro quinquênio, em linha com eventos que elevaram o tema em nível mundial. Nessa linha, sustentaram três registros: $1^{\circ}$ ) conteúdo do documento intitulado Limites do Crescimento do Clube de Roma, editado em 1972, que, de forma incisiva, tratou dos limites físicos do crescimento para manter o padrão de produção e consumo dominante; $2^{\circ}$ ) o resultado da Conferência das Nações Unidas sobre o Meio Ambiente, realizada em Estocolmo, no ano de 1972, com destaque para o equilíbrio entre desenvolvimento econômico e redução da degradação ambiental; e $3^{\circ}$ ) a criação do Programa das Nações Unidas para o Meio Ambiente (PNUMA), também de 1972, institucionalizando, neste organismo mul- tilateral, o tema do meio ambiente. Como resultado, a CEPAL defendeu a conservação da natureza e a superação da pobreza, como instrução a ser seguida pelos países (Bielschowsky, 2010).

Nesse período, o principal documento foi coordenado por Sunkel \& Gligo (1981), que seguiu a tradição cepalina de reflexão analítica sobre a conformação histórico-estrutural. A instituição propunha a necessidade de modificar o estilo de desenvolvimento, mediante estratégia que combinasse a luta contra a pobreza e desigualdade e a preservação do meio ambiente. $\mathrm{O}$ texto apresentou proposta para enfrentamento da questão ambiental e desenvolvimento e, em seu curso, criticou a reprodução na região do padrão de produção dos países centrais de uso intensivo de energia e de padrão de consumo que reproduz o estilo de vida dos países ricos. Tal processo constituía-se contra a defesa dos recursos naturais, devastando as florestas e contaminando os rios. Sugeria menos dependência do petróleo, uso mais intensivo da mão de obra, administração dos recursos naturais e tecnologia apoiada em bases ecológicas.

A discussão reinante de propor fomento à sustentabilidade ambiental com mudança no modo de produção se perdeu ao longo da década de 1980. A crise da dívida externa, processo inflacionário elevado, déficit público crônico, queda nos investimentos e rompimento do padrão de financiamento externo levaram a agenda da CEPAL a concentrar-se em temas voltados à solução para os problemas macroeconômicos. A questão ambiental não deixou de estar presente no quadro das preocupações e recomendações de política de desenvolvimento, tanto que continuou sendo debatido em eventos e protocolos que se sucederam, como a Convenção de Viena, Áustria (1985) e o Protocolo de Montreal 
(1987), discutindo, dentre outros temas, a proteção da camada de ozônio. Contudo, o tema perdeu espaço como objeto de preocupação na sua totalidade e voltou-se para questões específicas que afetavam o meio ambiente, como os causados pela expansão da fronteira agrícola e a construção de hidrelétricas, e não mais para uma eleição de políticas e ações abrangentes (Gligo, 2006; Bielschowsky, 2010).

Nos anos 1990, diante da reestruturação das economias, seguindo as propostas do Consenso de Washington, o tema do meio ambiente continuou subjacente ao modelo de desenvolvimento. Para Biechoswsky (2010, p. 70): “[...] la propuesta de fomentar la sostenibilidad ambiental, mediante um cambio radical de estilo de desarollo, perdió em forma gradual la posición destacada que tenia em la producción de la CEPAL". Alguns ensaios ocorreram por conta dos impactos dos eventos internacionais, como a Declaração do Rio sobre o Meio Ambiente, Rio 92, e a Convenção das Nações Unidas sobre Mudança Climática (1993), levando a CEPAL a dar maior atenção à gestão ambiental. O discurso na instituição apontava a submissão da dinâmica produtiva dos países ao processo de globalização, que, por si, não reduzem a pobreza e elevam a agressão ao meio ambiente.

Um dos principais documentos da década de 1990 postulava que o desenvolvimento deveria levar em consideração a equidade social e a sustentabilidade ambiental. Esse documento, "Transformação Produtiva com Equidade", apontou a necessidade de refinar e consolidar a sustentabilidade ambiental, como um dos caminhos para se alcançar o desenvolvimento. Nessa via, a CEPAL estimulou a criação de instituições e instrumentos que tratassem do meio ambiente, tais como ministério, secretarias e fundações do meio ambiente. E juntou-se ao Banco Interamericano de Desenvolvimento (BID), ao Banco Mundial, ao Programa das Nações Unidas para Desenvolvimento (PNUD) e ao Fórum dos Ministros de Meio Ambiente da América Latina e Caribe para a realização de esforços visando incorporar o meio ambiente nos documentos direcionadores de políticas (Bielchovsky, 2010).

\subsection{Dimensão ambiental na agenda de desenvolvimento da CEPAL nos anos 2000: equidade e inclusão social}

A partir dos anos 2000, a análise foi direcionada em relação aos documentos resultantes dos períodos de Sessões da CEPAL, que, segundo a ONU (2014), consistem no encontro bienal mais importante da comissão, quando se reúnem os 44 Estados membros e mais 12 associados de representantes do sistema da ONU e de organizações não governamentais para examinar as atividades realizadas e elencar as prioridades dos próximos anos. Nas Tabelas 2 e 3, são apontados elementos analíticos que compõem o pensamento cepalino em relação à dimensão ambiental, a partir do ano 2000. Detalha-se o título de cada período da sessão nos últimos dezoito anos e traz-se uma síntese das questões relativas ao meio ambiente, levantadas em cada um dos períodos.

Nessa perspectiva, ressalta-se a $28^{a}$ Sessão (2000) que teve como tema "Equidade, Desenvolvimento e Cidadania". Nesse encontro, a CEPAL reforçava a visão de desenvolvimento vinda da década anterior, pregadora da transformação econômica com equidade social. A instituição sugeriu a transformação da base produtiva fundada em 
processos inovativos, que incorporasse o respeito ao meio ambiente, dado que a agressão a ele gera efeitos negativos na sociedade. Essa orientação deveria proceder ancorada em novo pacto, envolvendo Estado, sociedade e mercado, em que a defesa do meio ambiente estivesse presente. Tal proposição foi fundada nos princípios da Conferência das Nações Unidas sobre o Meio Ambiente e o Desenvolvimento, realizada no Rio de Janeiro, Evento Rio 92, que indicara a construção de um modelo de desenvolvimento que se preocupasse com o uso dos recursos naturais e os impactos ambientais (CEPAL, 2002a).

A 29a Sessão (2002) abordou o tema "Globalização e Desenvolvimento". Nesse evento as discussões pautaram-se sobre problemas ambientais causados pela globalização da produção e do mercado, dentre os quais, o aquecimento global, a diminuição da biodiversidade, a redução da camada de ozônio e do avanço da desertificação. Segundo a instituição, as agressões ao meio ambiente se reproduzem dada a fragilidade institucional: legislação frouxa, falta de vigilância, recursos limitados para controle etc. $\mathrm{O}$ documento propôs políticas ativas de preservação, com destaque para a criação de impostos verdes, reduções de subsídios a atividades contaminantes, integração de políticas ambientais a políticas econômicas setoriais, e descentralização da gestão ambiental (CEPAL, 2002c)

A 30 a Sessão (2004) "Desenvolvimento Produtivo em Economias Abertas" dedicou atenção ao Protocolo de Cartagena e ao papel do Estado na defesa do meio ambiente. No tocante ao Protocolo, o documento da CEPAL ressaltou a necessidade de proteger a diversidade biológica dos riscos potenciais de organismos geneticamente modificados, resultantes da biotecnologia, pois podem gerar efeitos adversos na conservação e no uso sustentável da diversidade biológica. Em relação ao papel do Estado, apontou para a necessidade intervenções na economia, no intuito de preservar os recursos naturais e serviços ambientais, não podendo deixar que o mercado, por si só, faça a regulação. Dentre as políticas sugeridas, constava a criação de fundo ambiental, cujos recursos deveriam ser para subsidiar a intervenção (CEPAL, 2004).

$\mathrm{Na} 31^{\text {a }}$ Sessão (2006) da CEPAL, denominada "A Proteção Social de Cara ao Futuro", não se constatam menções sobre o meio ambiente. $\mathrm{O}$ documento, prioritariamente, destacou a necessidade de criação de um sistema de proteção social que garantisse direitos a todas as pessoas, independente de posicionamento social. A instituição defendeu, através de um pacto social, a cobertura universal e a garantia dos serviços de saúde, bem como a reforma dos sistemas de saúde (CEPAL, 2006). Por sua vez, na 32a Sessão (2008), “A Transformação Produtiva 20 Anos Depois", a instituição enfatizou o uso econômico da natureza e do meio ambiente por meio da biotecnologia. Observa, ainda, atenção à aplicação da biotecnologia e indicação para o tratamento de resíduos, biorremediação e purificação da água, sugerindo, o bioprocessamento nas indústrias têxtil, de couro e celulose, consideradas poluidoras (CEPAL, 2008).

A partir de 2010, observa-se maior atenção ao tema da igualdade ao redor da sustentabilidade ambiental. Na 33ª Sessão (2010), “A Hora da Igualdade: brechas por fechar e caminhos por abrir", foi enfatizado que a ordem coletiva e global exige maior igualdade e oportunidades de direitos para os indivíduos na sociedade. A instituição reconheceu que as mudanças climáticas serão cada vez mais destacadas na agenda internacional, e assumiu que imporá crescentes responsabilidades 
aos países. Reforçou a importância de incorporar o conceito da sustentabilidade e enfatizou a questão da segurança climática planetária no horizonte do desenvolvimento dos países. Destacou que devem ser modificadas as formas de produzir e de consumir e de gerar e de usar energia. Os processos produtivos devem conter menor conteúdo de carbono e maior convergência produtiva, que gere bem-estar aos menos favorecidos da sociedade (CEPAL, 2010).
Na 34 ${ }^{a}$ Sessão (2012), denominada "Mudança Estrutural para a Igualdade: uma visão integrada de desenvolvimento", a CEPAL considerou como vital rever o padrão de produção e crescimento, em linha com a sustentabilidade ambiental. O documento resultante enfatizou, novamente, que se deve rever o estilo de desenvolvimento menos contaminante do que os atuais, pois, no padrão atual, há forte correlação entre o crescimento do PIB, o consumo de energia e as emissões contaminantes. Posicio-

TABELA 2 - Síntese dos elementos analíticos que compõem o pensamento da CEPAL em relação à dimensão ambiental, 2000 - 2008.

\section{Sessões e Tema Central}

$28^{\mathrm{a}}$ Sessão (2000) -

Equidade,

Desenvolvimento e Cidadania

$29^{a}$ Sessão (2002) -

Globalização e Desenvolvimento

\section{Destaques}

Transformação produtiva e desenvolvimento inovativo devem incorporar o respeito ao meio ambiente; desenvolvimento competitivo e integrador em termos sociais, e sustentável em termos ambientais; promoção de pacto social entre Estado, mercado e sociedade na defesa do meio ambiente; e resgate de princípios da Rio 92.

Preocupação com aquecimento global, diminuição da biodiversidade, diminuição da camada de ozônio e avanço da desertificação; ressaltar a fragilidade institucional e econômica na área de meio ambiente; mudar padrões insustentáveis de consumo e produção que agride o meio ambiente; ressaltar a gestão sustentável dos ecossistemas e da diversidade biológica; e proposições: impostos verdes, reduções de subsídios a atividades contaminantes, integração de políticas ambientais e econômicas.

Repete alguns debates colocados anteriormente e cita o Protocolo de Cartagena sobre a segurança da biotecnologia; proposição de fundos para a gestão ambiental na região; papel do Estado: intervir para corrigir falhas de mercado para recursos naturais e serviços ambientais; e criação de fundo de recursos

$30^{\mathrm{a}}$ Sessão (2004) - Desenvolvimento Produtivo em Economias Abertas para ser aplicado em defesa do meio ambiente.

31 a Sessão (2006) -
A Proteção Social de Cara ao
Futuro.

$32^{\mathrm{a}}$ Sessão (2008) -

A Transformação Produtiva 20 anos Depois
Não há menção sobre o meio ambiente, e a questão da sustentabilidade ambiental não foi enfatizada; e ênfase à criação de um sistema de proteção social a todos, a despeito da posição social.

Enfatiza a utilização econômica da natureza e meio ambiente por meio da biotecnologia - natureza vista como um meio de desenvolvimento econômico; e sugere o tratamento de resíduos, biorremediação e purificação da água e bioprocessamento.

FONTE: Elaborado pelos autores, baseados em documentos da CEPAL (2002a; 2002c; 2004; 2006; 2008). 
nou-se em favor de atividades mais eficientes e intensivas em conhecimento e de menor impacto ambiental. Propôs o desenvolvimento de políticas que assegurem relação virtuosa entre crescimento, produtividade e sustentabilidade ambiental, com a incorporação de conhecimento e aumento do valor agregado. Sugeriu que os países desenvolvessem capacidades industrial, científica e tecnológica, no propósito de estimular inovação e aproveitar a grande diversidade de recursos naturais e de conhe- cimentos sobre a biodiversidade como vantagem competitiva (CEPAL, 2012).

A $35^{\mathrm{a}}$ Sessão (2014), "Pactos para a Igualdade: rumo a um futuro sustentável", apontou a necessidade de alcançar maiores graus de igualdade e de sustentabilidade no atual momento do desenvolvimento e frente às novas gerações na sociedade. A instituição, através do documento síntese, considerou a sustentabilidade ambiental uma equação pendente. Nesse curso, reconheceu que o estilo de desenvolvimento da região baseava-se

TABELA 2 - Síntese dos elementos analíticos que compõem o pensamento da CEPAL em relação à dimensão ambiental, 2000 - 2008

\section{Sessões e Tema Central}

$33^{\mathrm{a}}$ Sessão (2010)-

A Hora da Igualdade: brechas por fechar e caminhos por

abrir

$34^{\mathrm{a}}$ Sessão (2012) -

Mudança Estrutural para a Igualdade: uma visão integrada de desenvolvimento

\section{$35^{\mathrm{a}}$ Sessão (2014) -}

Pactos para a Igualdade: rumo a um futuro sustentável

36 Sessão (2016) -

Horizontes

2030: a igualdade no centro do DS

$37^{a}$ Sessão (2018) A Ineficiência da Desigualdade
Defende políticas que assegurem relação virtuosa entre crescimento, produtividade e sustentabilidade

Reforça o conceito da sustentabilidade do desenvolvimento no longo prazo; enfatiza a questão da segurança climática planetária; ressalta questões da eficiência energética; e destaca a promoção de avanços tecnológicos em processos produtivos com menos conteúdo de carbono.

\section{ambiental, com a incorporação de conhecimento e aumento do valor agregado.}

Critica a base produtiva dependente de recursos naturais; reforça o papel do Estado como impulsionador de políticas industriais que incorporem a inovação tecnológica para uma produção mais limpa e eficiente; reforça a ideia de pactos sociais; defende planejamento territorial com vistas à proteção da biodiversidade; investimentos em matrizes energéticas sustentáveis; e reforça a importância de uso racional da água como recurso estratégico.

Agenda 2030 para o DS, referendando os 17 Objetivos de DS, cujos princípios norteadores são a igualdade e a sustentabilidade; ênfase em questões de mudanças climáticas e confiança nos avanços tecnológicos para um crescimento com sustentabilidade; defesa do keynesianismo ambiental global; pactos sociais vistos como o caminho para o desenvolvimento ambiental sustentável; nova governança ambiental como saída a esse impasse; reconhecimento de barreiras a esse tipo de aliança; recuperar a confiança nas instituições; e defesa de um Estado democrático forte, aberto e transparente.

Desigualdade advinda da cultura de privilégios e ampliada pela financeirização globalizada, considerada sinônimo de ineficiência e fonte de vulnerabilidades (econômicas, sociais e ambientais); aumentar a penetração de energias renováveis na produção de eletricidade e no transporte; dar um grande impulso ambiental: reconhecimento da interdependência entre dimensões do desenvolvimento; criação de cidades sustentáveis e promoção de energias renováveis; e urgência em "não postergar a igualdade", mas incrementá-la para lograr um crescimento mais sólido e sustentável.

FONTE: Elaborado pelos autores, baseados em documentos da CEPAL (2010; 2012; 2014; 2016; 2018). 
em construção de vantagem competitiva estática de uso intensivo de recursos naturais, e defendeu a construção de uma estrutura que incorporasse a inovação tecnológica para uma produção mais limpa e eficiente. Propôs como política, que os países estabelecessem pactos, como os de governança dos recursos naturais e de preservação do meio ambiente. Defendeu o planejamento territorial com vistas à proteção da biodiversidade, investimentos em matrizes energéticas sustentáveis, reforçando a importância de uso racional da água como recurso estratégico (CEPAL, 2014).

A 36ª Sessão (2016), "Horizontes 2030: a igualdade no centro do desenvolvimento sustentável", referendou, no longo prazo, os princípios norteadores de igualdade e a sustentabilidade em linha com os 17 Objetivos do Desenvolvimento Sustentável (DS) da ONU. A instituição expressou que o estilo de desenvolvimento vem colocando em risco a sobrevivência humana e a de outras espécies, além de elevar os custos decorrentes dos fenômenos hidrometeorológicos extremos e do nível do mar. Defendeu o keynesianismo ambiental global. Nessa linha, citou a criação de estímulos fiscais que sustentem o nível de atividade e promovam a transformação da estrutura produtiva, fundada no conhecimento e na sustentabilidade. Reforçou a necessidade de se estabelecerem pactos sociais, como o ambiental. Reconheceu a existência de barreira para firmar uma governança ambiental que impulsione mudança estrutural, que garanta a inclusão social e combata os efeitos da mudança climática (CEPAL, 2016).

Na 37ª Sessão (2018), “A Ineficiência da Desigualdade", a CEPAL discutiu a cultura de privilégios e as condições ditadas pela financeirização globalizada, como sinônimos de ineficiência e fontes de várias vulnerabilidades, dentre as quais a ambiental. No tocante a essa, destacou os custos de tempo de deslocamento e a ineficiência das modalidades de transporte urbano, trazendo efeitos no padrão de consumo de energia, na poluição urbana e na saúde das pessoas. Enfatizou a crescente degradação do solo, compensada pelo uso de fertilizantes e pesticidas, que representam ameaça à saúde das pessoas e ao meio ambiente. Sugeriu que a revolução tecnológica pautasse pela mudança da matriz energética. E que os países dirigissem os processos produtivos para uso de baixo carbono e preservação do meio ambiente. Nesse sentido, "não postergar a igualdade", mas incrementá-la para lograr crescimento sólido e sustentável (CEPAL, 2018).

Para 2020, estava programada mais uma Sessão da CEPAL, que seria realizada em maio. Porém, em razão da pandemia do COVID 19, não se realizou, assim como todas as reuniões presenciais não foram realizadas. Esse fato suprime a possibilidade de se ter um novo documento de orientação estratégica para ser incorporado a esta análise. No entanto, a CEPAL (2020) publicou um documento especialmente dedicado à análise da pandemia, cujo título é "América Latina y el Caribe ante la pandemia del COVID-19: Efectos económicos y sociales". Nesse documento, a instituição aborda apenas os efeitos econômicos e sociais, não havendo menção ao pilar ambiental. Os escritos tratam da redução do investimento privado, da quebra de empresas, menor integração nas cadeias de valor, deterioração das capacidades produtivas e do capital humano; contudo, a dimensão ambiental ficou fora das questões abordadas.

\section{5. À guisa da conclusão: caminho ainda a}




\section{percorrer}

A CEPAL, como instituição multilateral vinculada à $\mathrm{ONU}$, tem papel importante na realização de estudos e em elaborar proposições de políticas de desenvolvimento para a América Latina e Caribe. Desde sua criação, em 1948, tem sugerido caminhos do desenvolvimento para os países membros em linha com as mudanças estruturais e conjunturais da economia mundial. No curso de pouco mais de 70 anos de história, os estudos realizados pautam-se por análises histórico-estruturais, sinalizando problemas que marcam as economias da região, dentre os quais a heterogeneidade da estrutura produtiva, distribuição desigual da renda, apática liderança da classe empresarial, estrutura da terra concentrada, pouco afeto à promoção de inovação, Estado pouco inclinado a promover transformações institucionais e o padrão de financiamento doméstico insuficiente.

As primeiras proposições de políticas de desenvolvimento da CEPAL foram voltadas à promoção da industrialização, via modelo de substituição de importações. Seguiram-se orientações voltadas à promoção de melhor distribuição de renda, dado que a industrialização se processara sem que os frutos dela fossem melhor distribuídos. No tempo, países assumiram elevados compromissos financeiros para se desenvolverem, e a orientação pautou-se pela renegociação das dívidas sem perder a preocupação com o crescimento. Seguiram orientações de como enfrentar a inflação, déficit público, desemprego, taxas de crescimento reduzidas e falta de investimentos tomaram corpos em sua agenda, em decorrência da macroeconomia perversa. Posteriormente, diante das orientações do Consenso de Washington, a CEPAL pregou o respeito às especificidades es- truturais dos países membros e nova reconfiguração do Estado desenvolvimentista.

Ainda que em muitos momentos históricos as orientações se voltassem, em maior dimensão, para o enfrentamento dos problemas macroeconômicos da região, a instituição manteve os estudos voltados a propor solução para a heterogeneidade estrutural. Nesse escopo, figura o desenvolvimento do progresso técnico, apontando que o processo de transformação produtiva, empreendido através da industrialização, não foi marcado por aprendizagem tecnológica e governos nacionais não priorizaram investimentos em P\&D como caminho a ser trilhado. As experiências asiáticas mostraram para a CEPAL a virtuosidade do processo inovativo quando eleito como uma das estratégias de construção de uma nação. Nesse propósito, a instituição recomendou a construção de sistemas nacionais de inovação, com atuação ativa de governo, universidade, instituto de pesquisas, sistema financeiro, empresariado e outros.

Por sua vez, a transformação produtiva, fundada na inovação, somou-se à orientação voltada para a defesa da equidade social, dado a região contar com pessoas que requerem tratamento diferenciado e políticas distintas na solução do mesmo problema. A essa orientação, posteriormente, somaria a defesa da igualdade de oportunidade a todos na sociedade. Estudos mostraram que a região da América Latina e Caribe é constituída por ativos produtivos e sociais altamente concentrados, que impedem o desenvolvimento social, limitando os acessos à informação, tecnologia, crédito, saúde, educação, saneamento básico, entre outros. Logo, a transformação social desejada requer que os países desenvolvam políticas que deem oportunidade a todos. Nesse sentido, a 
política de inclusão social passou a ser uma referência nas recomendações da CEPAL.

Nesse contexto de orientações, a temática do meio ambiente ingressou na agenda da CEPAL nos anos 1970 e 1980, de forma pontual e sem sequência de tratamento. Em tais décadas, chamaram a atenção os momentos de publicação de impacto e as conferências mundiais realizadas. Destaque para o documento elaborado pelo Clube de Roma e as conferências e protocolos, como a Conferência de Estocolmo, Convenção de Viena e Protocolo de Montreal. Seguiram os eventos internacionais, realizados nos anos 1990, outros eventos, como a Conferência do Rio de Janeiro sobre o Meio Ambiente, que possibilitaram à instituição manter o tema em sua agenda. Como essa década foi pautada pela reestruturação produtiva, reformulação do Estado e cumprimento de agenda liberal, a proposta de refinar e consolidar a sustentabilidade ambiental como um dos caminhos do desenvolvimento perdeu espaço no quadro de preocupação institucional.

Destarte, a orientação cepalina em relação ao meio ambiente recebeu, de fato, maior atenção nos anos 2000, quando, no bojo da discussão do tema globalização e desenvolvimento, emergiu, de forma mais acentuada, ligada à preocupação com as mudanças climáticas, decorrentes do processo de aquecimento global. Associaram-se à realização de outros eventos internacionais, colocando em evidência a defesa do meio ambiente no contexto internacional, eventos como o Rio +10 e Rio +20 . Toma corpo, no cenário internacional, discussões sobre o tema do desenvolvimento atrelado às ocorrências com o meio ambiente. Os registros das Sessões Temáticas, realizadas em encontros bianuais da CEPAL, mostram que o tema deixou de ser pontual e passou a estar presente no quadro das principais orientações desenvolvimentistas.

No curso das seções realizadas na primeira década desse século XXI, as principais orientações em relação ao meio ambiente foram: a) transformação da base produtiva, incorporando o meio ambiente através de pactos entre o Estado, o mercado e a sociedade (Sessão de 2000); b) políticas ativas de preservação, como o imposto verde, a redução de subsídios a atividades contaminadoras e a integração de políticas setoriais com a ambiental (Sessão de 2002); c) proteção da diversidade biológica de riscos geneticamente melhorados e defesa da intervenção estatal na regulação do meio ambiente (Sessão de 2004); d) utilização da biotecnologia em tratamento de resíduos e bioprocessamento industrial em atividades econômicas poluidoras (Sessão de 2008); e) incorporação do conceito de sustentabilidade e discurso a favor da mudança no padrão produtivo com menor uso de energia não renovável (Sessão de 2010).

Em continuidade, na segunda década dos anos 2000, a temática ambiental continuou presente no discurso da CEPAL, cujas principais orientações expressas nos documentos dos eventos foram: f) defesa da mudança estrutural fundada no conhecimento e de menor impacto ambiental, desenvolvendo capacidades estimuladoras de inovação aproveitadora da diversidade dos recursos naturais e do conhecimento sobre o ecossistema (Sessão de 2012); g) criação de governança ambiental, planejamento voltado à proteção da biodiversidade $\mathrm{e}$ investimentos em energia sustentável (Sessão de 2014); h) defesa do keynesianismo ambiental com participação do Estado financiando, subsidiando e incentivando atividades produtivas limpas a partir de pactos sociais (Sessão de 2016); e i) ênfase em 
revolução tecnológica que promova transformação produtiva, utilizando matriz energética renovável e preservadora do meio ambiente (Sessão de 2018).

Fica evidente que a dimensão ambiental do desenvolvimento foi sendo incorporada nos documentos cepalinos, alcançando maior ênfase nos anos 2000. Até então, figurou como posição secundária nas discussões, mesmo que, em alguns momentos, o tema fosse retomado em sincronia com eventos, que reforçaram a discussão em âmbito mundial. A instituição reconheceu que o modelo de desenvolvimento fora marcado pelo aproveitamento dos recursos naturais pela matriz produtiva. Admitiu que, ao longo do tempo, não se logrou um tipo de desenvolvimento ambientalmente responsável. E os últimos escritos das Sessões Temáticas reforçaram a necessidade de mudar o padrão de produção via uso de energia renovável e de tecnologias limpas.

Há reconhecimento de que ocorreram avanços institucionais - legislação e instrumentos -, mas as ações levadas a cabo pelos países não têm sido eficazes para a solução dos problemas ambientais. Problemas estruturais, citados em documento na primeira década dos anos 2000, dentro da CEPAL, perseguem na segunda década desse século: $1^{\circ}$ ) os investimentos diretos externos querem legislação ambiental favorável; $2^{\mathrm{a}}$ ) economias nacionais deparam-se com necessidade de gerar divisas, expõem a exploração intensiva dos recursos naturais; $3^{\mathrm{a}}$ ) falta de recursos para controle ambiental, e investigações científicas insuficientes; $4^{\mathrm{a}}$.) estrutura industrial doméstica dos países voltada para a exploração dos produtos da natureza; e, $5^{\text {a }}$ ) o meio ambiente é considerado como externalidades da aquisição de insumos e tratamento de resíduos (Gligo, 2006).

A CEPAL reconhece que a defesa do meio ambiente constitui um tema que incomoda e, por consequência, não se converte em sujeito político. Afirma, em documento, que a tecnoburocracia do Estado manipula a temática em concordância com os interesses de setores empresariais. Com isso, o tema é controlado e pouco conflitivo. As ONGs, que poderiam ser ponto de resistência e de pedido de mudança, encontram-se reduzidas em número e em participantes. As legislações são feitas de tal forma que não se dedicam em alterar o status quo dominante. E mais, são elaboradas de tal forma que as condições econômicas e políticas que pautam a dimensão ambiental. Em reforço, ministérios, secretarias e fundações do meio ambiente deparam-se com recursos humanos limitados, recursos financeiros precários e não possuem capacidade de coordenação em arranjos que tratam do tema. E a ausência ou o pouco conhecimento da população sobre a realidade ambiental, torna a consciência coletiva difusa e dispersa (Gligo, 2006).

Reconhece-se que a CEPAL não é governo de país membro, mas tem a função de realizar estudos e propor políticas de desenvolvimento para os países membros que poderão ou não as aceitar, sem nenhum poder obrigatório de cumprimento. Assim, ressalta-se que há ainda muito caminho a percorrer. O tripé do desenvolvimento sustentável tem, pela parte ambiental, menor consideração na agenda, ainda que se tenham registrado avanços nos anos 2000. A prioridade parece estar na economia, como sinônimo de crescimento, e na redução das desigualdades sociais. A questão ambiental mantém-se relegada a uma posição de segunda ordem, como uma equação pendente.

O último documento publicado (CEPAL, 2020) aborda os efeitos da pandemia do Coronavírus 19 , porém, faz referência à questão ambiental, dedicando-se a analisar a utilização dos mesmos ele- 
mentos clássicos do desenvolvimento, os aspectos econômicos e sociais, desvinculados da dimensão ambiental. É evidente que a pandemia do Coronavírus 19 é uma grave crise sanitária de alcance global, com consequências sociais, econômicas e políticas nefastas que devem induzir transformações estruturais ainda impossíveis de se predizer. Por ser um processo em curso quando da finalização deste ensaio, qualquer especulação dos seus reais efeitos nas reflexões e orientações da CEPAL seria pouco prudente. Ainda assim, é esperado que a organização se dedique a investigar possíveis relações entre este tipo de fenômeno de alcance global e estratégias de desenvolvimento mais adequadas para países da região. Essa nova realidade inexoravelmente deve impor a dimensão sanitária na equação do desenvolvimento, o que, se supõe, pode beneficiar uma visão mais assertiva com relação à importância e sensibilidade da dimensão ambiental nas perspectivas de desenvolvimento de longo prazo preconizadas pela CEPAL.

Em continuidade, é a natural recomendação de caráter normativo seria a de incorporar a dimensão ambiental no marco analítico cepalino, com o sentido de agregar, de maneira clara e explícita, a "natureza" como base biofísica da vida, seja urbana ou rural. Essa base, deve se ressaltar, se encontra numa situação cada vez mais crítica decorrente de movimentos de apropriação ilimitada, com sinais claros de exaustão sistêmica (vide os últimos eventos climáticos e epidemiológicos globais). Assim, ainda que prepondere um conceito de "natureza" considerada sob um viés econômico, como sinônimo de "recursos naturais", que inclua valores e valorize florestas, mananciais, rios e mares, toda a biodiversidade da região (uma das maiores e mais diversas do mundo), o meio ambiente deve ser protegido e receber atenção como parte dos ativos, algo a ser preservado ou, no mínimo, visto com cuidado especial que um ativo desse porte tem numa idealizada equação de desenvolvimento.

Do contrário, é inevitável que o processo de desmaterialização das economias dos países centrais, em curso pela via de padrões cada vez mais restritos de contaminação e utilização de recursos naturais, estabelecidos por países mais desenvolvidos, siga exportando externalidades ambientais e sociais negativas para as economias periféricas (Tanimoto, 2010), sem possibilidades concretas de diminuírem-se as assimetrias históricas evidenciadas pela CEPAL desde sua criação.

\section{Referências}

Almeida, J. E. Subdesenvolvimento e dependência: uma análise comparada de Celso Furtado e Fernando Henrique Cardoso. Porto Alegre, Tese (Doutorado em Economia) UFRGS, 2009.

Bárcena, A. Prólogo. In: CEPAL, Pactos para la igualdad: hacia un futuro sostenible. Santiago: CEPAL, p. 13 -17, 2014.

Batista Jr., P. N. Mito e realidade da divida externo brasileira. Rio de Janeiro: Paz e Terra, 1983.

Batista, P. N. O Consenso de Washington: a visão neoliberal dos problemas latino-americanos. Rio de Janeiro, 1994 (mimeo).

Bielschowsky, R. Cinquenta anos de pensamento na CEPAL - uma resenha. In: Bielschowsky, R. (Org.). Cinquenta anos de pensamento na CEPAL. Rio de Janeiro: Record, p. $15-68,2000$.

Bielschowsky, R. C. F. Celso Furtado e o pensamento econômico latino-americano. In: Bresser Pereira, L. C.; Rego, J. M. (Orgs.). A grande esperança em Celso Furtado. São Paulo: Ed. 34, p. 130-151, 2001. 
Bielschowsky, R. Pensamento econômico brasileiro: ciclo ideológico do desenvolvimento. Rio de Janeiro: Contraponto. 2007.

Bielschowsky, R. Sesenta años de la CEPAL y pensamento reciente. In: Bielschowsky R. (Org.). Sesenta años de la CEPAL: textos seleccionados del decênio 1998-2008. Buenos Aires: Siglo Veintiuno Editores, p.15-78, 2010.

Bresser Pereira, L. C. Estratégia nacional e desenvolvimento. Revista de Economia Política, 26, 2(102), 203-230, 2006. Disponível em: https://www.scielo.br/pdf/rep/v26n2/ a03v26n2.pdf

Bresser-Pereira, L. C. Do antigo ao novo desenvolvimentismo na América Latina. In: Prado, L. C. D. (Org.). Desenvolvimento econômico e crise - ensaios em comemoração aos 80 anos de Maria da Conceição Tavares. SP: Contraponto Editora, p. 27-66, 2012a.

Bresser Pereira, L. C. Desenvolvimentismo: a ideologia do desenvolvimento nos países retardatários. Revista do Instituto Humanita Unisinos, 392, 2012b. Disponível em: http://www.ihuonline.unisinos.br/artigo/4422-luiz-carlos-bresser-pereira-2

Cardoso, F. H.; Faletto, E. Dependência e desenvolvimento na América Latina - ensaio de interpretação sociológica. Rio de Janeiro: Zahar, 1970.

Cardoso de Mello, J. M. O capitalismo tardio. São Paulo: Brasiliense, 10. ed., 1998.

Carneiro, R de M. Desenvolvimento em crise: a economia brasileira no último quarto do século XX. São Paulo: Editora UNESP, IE - UNICAMP, 2002.

CEPAL - Comissão Econômica para a América Latina e Caribe. Transformação produtiva com equidade. Santiago - Chile: CEPAL, 1996.

CEPAL - Comissão Econômica para a América Latina e Caribe. Equidade, desenvolvimento e cidadania. Vigésimo oitavo período de sessão da CEPAL. Cidade do México, México: CEPAL, 2002a.

CEPAL - Comissão Econômica para a América Latina e Caribe. A sustentabilidade do desenvolvimento na América Latina e Caribe: desafios e oportunidades. Livros da CEPAL $\mathrm{N}^{\circ}$ 68, Santiago, Chile: CEPAL, $2002 \mathrm{~b}$.
CEPAL - Comissão Econômica para a América Latina e Caribe. Globalização e desenvolvimento. Síntese. Vigésimo nono período de sessão da CEPAL. Brasília: CEPAL, 2002c.

CEPAL - Comissão Econômica para a América Latina e Caribe. Desenvolvimento produtivo em economias abertas. Síntese. Trigésimo período de sessões da CEPAL. San Juan, Porto Rico: CEPAL, 2004.

CEPAL - Comissão Econômica para a América Latina e Caribe. Enfrentando o futuro da proteção social: acesso, financiamento e solidariedade. Síntese. Trigésimo primeiro período de sessões da CEPAL. Montevidéu, Uruguai: CEPAL, 2006.

CEPAL - Comissão Econômica para a América Latina e Caribe. Coesão social: inclusão e sentido de pertencimento na América Latina e Caribe. Santiago de Chile: CEPAL, 2007a.

CEPAL - Comissão Econômica para a América Latina e Caribe. Panorama social de América Latina. Santiago de Chile: CEPAL, 2007b.

CEPAL - Comissão Econômica para a América Latina e Caribe. Progresso técnico e câmbio estrutural na América Latina. Documentos de Projetos, $n^{\circ} 136$. Santiago de Chile: CEPAL, 2007c.

CEPAL - Comissão Econômica para a América Latina e Caribe. A transformação produtiva após 20 anos: velhos problemas, novas oportunidades. Síntese. In:Trigésimo segundo período de sessões da CEPAL. Santo Domingo, República Dominicana, 9 a 13 de junho de 2008.

CEPAL - Comissão Econômica para a América Latina e Caribe. A hora da igualdade - brechas por selar, caminhos por abrir. Síntese. In:Trigésimo terceiro período de sessões da CEPAL. Brasília, Brasil, 30 de maio a 01 de junho, 2010.

CEPAL - Comissão Econômica para a América Latina e Caribe. Mudança estrutural para a igualdade: uma visão integrada do desenvolvimento. Síntese. In: Trigésimo quarto período de sessões da CEPAL. San Salvador, El Salvador, 27 a 31 de agosto, 2012

CEPAL - Comissão Econômica para a América Latina e Caribe. Informação histórica: evolução das ideias da CEPAL, 2013. Disponível em: <http://www.cepal.org/cgibin/ getprod.asp?xml=/noticias/paginas/4/13954/P13954.xml\&x 
$\mathrm{sl}=/ \mathrm{tpl} / \mathrm{p} 18 \mathrm{f}-\mathrm{st} . \mathrm{xsl} \&$ base $=/$ tpl/top-bottom.xsl $>$. Acesso em: jan. 2020.

CEPAL - Comissão Econômica para a América Latina e Caribe. Pactos para a igualdade rumo a um futuro sustentável. Síntese. In: Trigésimo quinto período de sessões da CEPAL. Lima, Peru. 5 a 9 de maio, 2014.

CEPAL - Comissão Econômica para a América Latina e Caribe. Horizonte 2030 - a igualdade no centro do desenvolvimento sustentável. Síntese. In: Trigésimo sexto período de sessões da CEPAL, Cidade do México, 23 a 27 de maio, 2016.

CEPAL - Comissão Econômica para a América Latina e Caribe. A ineficiência da desigualdade. Síntese. In: Trigésimo sétimo período de sessões da CEPAL. Havana, Cuba, 07 a 11 de maio. 2018.

CEPAL - Comissão Econômica para a América Latina e Caribe. Informe especial COVID-19: América Latina e Caribe frente a pandemia do COVID 19 - efeitos económicos e sociais, 2020. Disponível em: <América Latina y el Caribe ante la pandemia del COVID-19: efectos económicos y sociales | Publicación | Comisión Económica para América Latina y el Caribe (cepal.org)>. Acesso em: mai. 2020.

Colistete, R. P. O desenvolvimentismo cepalino: problemas teóricos e influências no Brasil. Estudos Avançados, 15(41), 21-34, 2001. doi: 10.1590/S0103-40142001000100004

Cruz, P. D. Dívida externa e política econômica. São Paulo: Brasiliense, 1984.

Draibe, S. Rumos e metamorfoses - Estado e industrialização no Brasil - 1930/1960. Rio de Janeiro: Paz e Terra, 1985.

Fajnzylber, F. Industrialización trunca de América Latina. México, D. F: Nueva Imagem, 1983.

Fajnzylber, F. Industrialización en América Latina: de la caja negra al casillero vacío. Cuadernos de la CEPAL, 60, 1990. Disponível em: https://repositorio.cepal.org/handle/11362/27955

Fonseca, P. C. D. As origens e as vertentes formadoras do pensamento cepalino. Revista Brasileira de Economia. 54(3) 333-358, 2000. doi: 10.1590/S0034-71402000000300004

Fonseca, P. C. D Desenvolvimentismo: a construção do conceito. In: Calixte, A.; Biancarelli, A.; Cintra, M. (Eds.). Presente e futuro do desenvolvimento no Brasil. Brasília: IPEA, p. 9-52, 2014.

Furtado, C. O subdesenvolvimento revisitado. Economia e Sociedade, 1(1), 5-19, 1992. Disponível em: https:// periodicos.sbu.unicamp.br/ojs/index.php/ecos/article/ view/8643307

Gibbs, G. Análise de dados qualitativos. Porto Alegre: Artmed, 2009.

Gil, A. C. Como elaborar projetos de pesquisa. São Paulo: Atlas, 4. ed., 2008.

Gligo, N. Estilos de desarrollo y medio ambiente en América Latina, un cuarto de siglo después, serie Medio ambiente y desarrollo, 126, Publicación de las Naciones Unidas. Santiago de Chile: CEPAL, 2006.

Marconi, M. de A.; Lakatos, E. M. Fundamentos de metodologia cientifica. São Paulo: Atlas, 5. ed.,2003.

Marini, R M. Dialética da dependência. Post-scriptum traduzido por Carlos Eduardo Martins, Universidade Estácio de Sá, Rio de Janeiro, RJ. México: Editora Era, 10. ed., 1990.

Marini, R. M. Dialética da dependência. In: Transpadini, R., Stélide, J. P. (Org.). Rui Mauro Marini, vida e obra. São Paulo: Expressão Popular, 2011.

Olivos, M. T (Org.). Fernando Fajnzylber: uma visão renovadora del desarrollo em América Latina. Santiago - Chile: CEPAL, 2006.

ONU - Organização das Nações Unidas. La CEPAL celebrará su próximo período de sesiones en Lima, 2014. Disponível em: <https://www.cepal.org/pt-br/comunicados/ lima-acolhera-em-maio-o-proximo-periodo-de-sessoes-da-cepal>. Acesso em: jun. 2016.

Paiva, S. C. Estratégias de politica industrial e desenvolvimento econômico: ideias de Fernando Fanjzylber para a América Latina. Campinas, Tese (Doutorado em Economia Aplicada) - UNICAMP, 2006.

Portella Filho, P. A moratória soberana: considerações sobre o não pagamento da dívida externa brasileira. Campinas, Tese (Doutorado em Economia) - UNICAMP, 1987.

Prado, F. C. A ideologia do desenvolvimento e a controvérsia 
da dependência no Brasil contemporâneo. Rio de Janeiro, Tese (Doutorado em Economia Política Internacional). UFRJ, 2015.

Prebisch, R. Problemas teóricos y prácticos del crecimiento económico. Santiago de Chile: CEPAL, 1973.

Sunkel, O. Política nacional de desarrollo y dependência externa. Estudios Internacionales, 1(1), 48- 75, 1967. doi: 10.5354/0719-3769.2012.19315

Sunkel, O.; Gligo, N. (Comps.). Estilos de desarrollo y médio ambiente en la América Latina, México, D.F: Fondo de Cultura Económica, 1981.

Tanimoto, A. H. A economia medida pela Análise de Fluxo de Massa (AFM): a desmaterialização da economia nos países desenvolvidos sustentada pelos recursos naturais dos países emergentes, a exemplo do Brasil. Brasília, Tese (Doutorado em Desenvolvimento Sustentável) - UnB, 2010.

Tavares, M. C. A retomada da hegemonia norte-americana. Revista de Economia Política, 5(2), 5 - 15, 1985. Disponível em: https://rep.org.br/rep/index.php/journal/article/ view/1839

Tavares, M. C.; Serra, J. Além da estagnação: uma discussão sobre o estilo de desenvolvimento recente no Brasil. In: Bielschowsky, R. Cinquenta anos de pensamento na CEPAL. Rio de Janeiro: Record/CEPAL, p. 589-608, v. 2, 2000.

Teixeira, A. O movimento da industrialização nas economias capitalistas centrais no pós-guerra. Dissertação (Mestrado em Economia) - UFRJ, 1983.

Torres, M. (Comp.). Fernando Fajnzylber: una visión renovadora del desarrollo en América Latina. Libros de la CEPAL, n. 92. Publicación de las Naciones Unidas. Santiago de Chile: CEPAL, 2006.

Triviños, A. N. S. Introdução à pesquisa em ciências sociais: a pesquisa qualitativa em educação. São Paulo: Atlas, 2007. 